\title{
Viable cold-tolerant iron-reducing microorganisms in geographically diverse subglacial environments
}

\author{
Sophie L. Nixon ${ }^{1}$, Jon P. Telling ${ }^{2}$, Jemma L. Wadham $^{3}$, and Charles S. Cockell ${ }^{4}$ \\ ${ }^{1}$ School of Earth and Environmental Sciences, University of Manchester, Manchester, M13 9PL, UK \\ ${ }^{2}$ Department of Civil Engineering and Geosciences, Newcastle University, Newcastle, NE1 7RU, UK \\ ${ }^{3}$ School of Geographical Sciences, University of Bristol, Bristol, BS8 1SS, UK \\ ${ }^{4}$ UK Centre for Astrobiology, School of Physics and Astronomy, University of Edinburgh, Edinburgh, EH9 3FD, UK \\ Correspondence to: Sophie L. Nixon (sophie.nixon@manchester.ac.uk)
}

Received: 29 July 2016 - Discussion started: 17 August 2016

Revised: 2 January 2017 - Accepted: 4 January 2017 - Published: 21 March 2017

\begin{abstract}
Subglacial environments are known to harbour metabolically diverse microbial communities. These microbial communities drive chemical weathering of underlying bedrock and influence the geochemistry of glacial meltwater. Despite its importance in weathering reactions, the microbial cycling of iron in subglacial environments, in particular the role of microbial iron reduction, is poorly understood. In this study we address the prevalence of viable iron-reducing microorganisms in subglacial sediments from five geographically isolated glaciers. Iron-reducing enrichment cultures were established with sediment from beneath Engabreen (Norway), Finsterwalderbreen (Svalbard), Leverett and Russell glaciers (Greenland), and Lower Wright Glacier (Antarctica). Rates of iron reduction were higher at $4{ }^{\circ} \mathrm{C}$ compared with $15^{\circ} \mathrm{C}$ in all but one duplicated secondgeneration enrichment culture, indicative of cold-tolerant and perhaps cold-adapted iron reducers. Analysis of bacterial 16S rRNA genes indicates Desulfosporosinus were the dominant iron-reducing microorganisms in low-temperature Engabreen, Finsterwalderbreen and Lower Wright Glacier enrichments, and Geobacter dominated in Russell and Leverett enrichments. Results from this study suggest microbial iron reduction is widespread in subglacial environments and may have important implications for global biogeochemical iron cycling and export to marine ecosystems.
\end{abstract}

\section{Introduction}

Despite cold, dark and oligotrophic conditions subglacial environments worldwide harbour diverse microbial communities. Such communities have been documented at the icebed interface of valley glaciers (Sharp et al., 1999; Skidmore et al., 2005; Buzzini et al., 2005; Bhatia et al., 2006; Kaštovská et al., 2007; Mitchell et al., 2013; Hamilton et al., 2013), ice sheets (Sheridan et al., 2003; Mikucki and Priscu, 2007; Lanoil et al., 2009), and in subglacial lakes (Priscu et al., 1999; Gaidos et al., 2004; Marteinsson et al., 2013; Christner et al., 2014). Given the absence of light in these environments, microbially mediated redox reactions fuel heterotrophic and autotrophic microbial metabolism and drive chemical weathering reactions of the underlying bedrock (Sharp et al., 1999; Bottrell and Tranter, 2002; Tranter et al., 2005; Wynn et al., 2006; Hodson et al., 2008; Montross et al., 2012; Boyd et al., 2014). To date, subglacial microbiology research has focused on the microbial cycling of carbon (Boyd et al., 2011; Stibal et al., 2012), nitrogen (Skidmore et al., 2000; Boyd et al., 2011) and sulfur (Boyd et al., 2014; Harrold et al., 2016). The role of microbial iron cycling, and in particular iron(III) reduction, in subglacial biogeochemical cycling is poorly understood. This is surprising, given the importance of iron in (a) catalysing the weathering of bedrock sulfides and promoting solute production (Bottrell and Tranter, 2002), (b) influencing phosphorus availability to microorganisms via adsorption-desorption reactions on Fe(III) oxide surfaces (Gunnars et al., 2002) and (c) the potential for subglacially derived iron to impact global biogeochemical cy- 
cles by fertilizing productivity in downstream ecosystems, including those in marine environments (Death et al., 2014).

Recent research has shown the flux of bioavailable nanoparticulate iron associated with glacial runoff from ice sheets to be an important source of nutrients to the surrounding oceans (Hawkings et al., 2014). These iron oxyhydroxide particles are thought to originate from the oxidation of dissolved ferrous iron from anoxic subglacial environments. The source of this Fe(II) remains unknown, though microbial iron reduction is a plausible but untested explanation (Hawkings et al., 2014).

Although a number of studies have demonstrated the presence of iron-reducing microorganisms in subglacial environments using culture-independent methods (Skidmore et al., 2005; Mikucki and Priscu, 2007; Lanoil et al., 2009; Yde et al., 2010; Marteinsson et al., 2013; Mitchell et al., 2013), few studies have addressed their viability (Foght et al., 2004; Mikucki and Priscu, 2007) or their physiological characteristics. Our hypothesis is that subglacial sediments harbour active microorganisms that are capable of carrying out microbial iron reduction. Specifically, our aims in this study are (1) to assess whether subglacial sediments harbour active iron-reducing microorganisms and (2) whether these microorganisms are adapted to low temperatures. We present data from enrichment cultures initiated from subglacial sediments entombed in basal ice, sampled at the glacier margins of five glaciers geographically isolated from one another: Engabreen, Norway; Russell and Leverett glaciers, Greenland; Finsterwalderbreen, Svalbard; and Lower Wright Glacier, Antarctica. We demonstrate that viable iron-reducing microorganisms are present in each of these systems and that they are tolerant of, and may even be adapted to, low temperatures.

\section{Materials and methods}

\subsection{Sample sites and subglacial sample acquisition}

Engabreen $\left(\mathrm{E} ; 66^{\circ} 41^{\prime} \mathrm{N}, 13^{\circ} 46^{\prime} \mathrm{E}\right)$ is a temperate glacier of the western Svartisen Icecap in northern Norway. The underlying bedrock is metamorphic, dominated by schists and gneisses with calcite-filled cracks (Jansson et al., 1996), and contains relatively little organic carbon (O'Donnell et al., 2016). The bedrock and basal ice is accessible through a system of underground tunnels leading to the glacier bed from the Svartisen Subglacial Laboratory. This basal ice was sampled by implementing hot-water drilling, and sedimentladen ice removed from the resulting cavity $200 \mathrm{~m}$ below the glacier surface using a chainsaw (Stibal et al., 2012).

Russell (R; $67^{\circ} 03^{\prime} \mathrm{N}, 50^{\circ} 10^{\prime} \mathrm{W}$ ) and Leverett (L; $67^{\circ} 03^{\prime} \mathrm{N}, 50^{\circ} 07^{\prime} \mathrm{W}$ ) are neighbouring land-terminating outlet glaciers. Together they constitute a large discharge lobe emanating from the western Greenland Ice Sheet (GrIS); Leverett is the southern offshoot of the larger Russell Glacier.
Both are polythermal (cold and warm-based regions exist at the ice-bed interface), but warmer conditions dominate, as evidenced by accelerated glacial flow at the onset of the melt season (Sundal et al., 2011). The underlying bedrock is metamorphic, dominated by Archaean gneiss, which was subsequently reworked in the Early Proterozoic (Henrikson et al., 2000) and during numerous Holocene re-advances, leading to the incorporation of organic matter (Ten Brink and Weidick, 1974). At Russell Glacier, samples were obtained from upthrusted subglacial sediment near the terminus. The outermost surface of the ice was removed using a chainsaw before subsampling the remaining sediment-laden ice (Stibal et al., 2012). Two subglacial samples were collected from Leverett; $\mathrm{L}$ was chainsawed from a pressure ridge at the glacier margin, believed to be subglacial in origin, and FL ("fresh" Leverett) was collected from the basal sediments at the ice-bed interface within an ice cave using a flame-sterilized spatula. At the time of collection, the latter sediment (FL) was assumed to be freshly melted.

Finsterwalderbreen $\left(\mathrm{F} ; 77^{\circ} 28^{\prime} \mathrm{N}, 15^{\circ} 18^{\prime} \mathrm{E}\right)$ is a polythermal glacier on the southern side of Van Keulenfjorden, Spitsbergen, Svalbard (Wadham and Nuttall, 2002). Similar to the Greenland glaciers, the thermal regime of this glacier is largely warm-based (Hodson and Ferguson, 1999). The major underlying geology is mainly sedimentary, comprising sandstone, siltstone, shale, limestone and dolomites (Dallmann et al., 1990). Basal sediment was removed using a chainsaw from a pressure ridge at the glacier terminus (O’Donnell et al., 2016).

Lower Wright $\left(\mathrm{LW} ; 77^{\circ} 25^{\prime} \mathrm{S}, 163^{\circ} 0^{\prime} \mathrm{E}\right)$ is a cold-based glacier draining westwards from the Wilson Piedmont Glacier in the McMurdo Dry Valleys region of Antarctica. The glacier currently terminates in the permanently icecovered Lake Brownworth (Stibal et al., 2012). The underlying bedrock is dominated by granite-gneisses (Hall and Denton, 2002); however, during the last few centuries numerous glacial advances have overridden and reworked lake sediments, evidence of which was found in the presence of algal matter in subglacial sediment (Wadham et al., 2012). The sampling site featured exposed frozen sediment sandwiched between layers of pure glacial ice at the interface of the ice-covered lake and the terminal moraines of the glacier. Blocks of this debris-laden ice were removed using a chainsaw (Stibal et al., 2012).

Samples were transported frozen from the field site to LOWTEX (University of Bristol) and stored at $-20^{\circ} \mathrm{C}$. Samples were prepared at the LOWTEX facility prior to their use in this study. Specifically, sediment-laden basal ice was placed in a laminar-flow hood in pre-furnaced glass beakers and the outer layer of each sample was removed by washing with sterile deionized water. Samples were covered in furnaced aluminium foil and transferred to an anaerobic chamber, where they were thawed under $100 \%$ nitrogen atmosphere. The liberated sediment from basal ice samples was subsampled into sterile serum vials, crimp-sealed with thick 
butyl rubber stoppers and aluminium caps, and removed from the chamber. The headspace of each was immediately flushed with $\mathrm{N}_{2}$ gas for $1 \mathrm{~min}$ using sterile needles attached to sterile $0.2 \mu \mathrm{m}$ syringe filters, before being transferred to the University of Edinburgh, where they were stored at $4{ }^{\circ} \mathrm{C}$ for $24 \mathrm{~h}$ before enrichments were initiated.

\subsection{Microbial enrichment cultures}

Strict anaerobic culturing techniques were used throughout (Miller and Wolin, 1974). Enrichment cultures were initiated by adding sterile anoxic freshwater basal medium at $\mathrm{pH}$ 6.87.0 to serum vials containing subglacial sediments. The basal medium contained (grams per L deionized water) $\mathrm{NaHCO}_{3}$ (2.5), $\mathrm{NH}_{4} \mathrm{Cl}(0.25), \mathrm{NaH}_{2} \mathrm{PO}_{4}(0.06), \mathrm{KCl}(0.1), 10 \mathrm{~mL}$ vitamin solution and $10 \mathrm{~mL}$ trace elements solution. The vitamin solution contained $\left(\mathrm{mg} \mathrm{L}^{-1}\right.$ deionized water) biotin (2.0), folic acid (2.0), pyridoxine- $\mathrm{HCl}$ (10.0), riboflavin (5.0), thiamine (5.0), nicotinic acid (5.0), pantothenic acid (5.0), vitamin B-12 (0.1), p-aminobenzoic acid (5.0), and thioctic acid (5.0). The trace elements solution contained $\left(\mathrm{g} \mathrm{L}^{-1}\right.$ deionized water) nitrilotriacetic acid (1.5), $\mathrm{MgSO}_{4}(3.0), \mathrm{MnSO}_{4} \cdot \mathrm{H}_{2} \mathrm{O}$ (0.5), $\mathrm{NaCl}(1.0), \mathrm{FeSO}_{4} .7 \mathrm{H}_{2} \mathrm{O}(0.1), \mathrm{CaCl}_{2} .2 \mathrm{H}_{2} \mathrm{O}(0.1)$, $\mathrm{CoCl}_{2} \cdot 6 \mathrm{H}_{2} \mathrm{O}(0.1), \mathrm{ZnCl}_{2} \quad(0.13), \mathrm{CuSO}_{4} .5 \mathrm{H}_{2} \mathrm{O}$ (0.01), $\mathrm{AlK}\left(\mathrm{SO}_{4}\right)_{2} .12 \mathrm{H}_{2} \mathrm{O}(0.01), \mathrm{H}_{3} \mathrm{BO}_{3}(0.01), \mathrm{NaMoO}_{4}(0.025)$, $\mathrm{NiCl}_{2} \cdot 6 \mathrm{H}_{2} \mathrm{O}(0.024)$ and $\mathrm{NaWO}_{4} .2 \mathrm{H}_{2} \mathrm{O}(0.025)$. Vitamin and trace element solutions were stored at $4{ }^{\circ} \mathrm{C}$ in the dark. Enrichments were supplemented with acetate $(10 \mathrm{mM})$ and lactate $(10 \mathrm{mM})$ as the electron donors and poorly crystalline Fe(III) oxide ( $\sim 100 \mathrm{mM})$ as the terminal electron acceptor. This combination of electron donors was chosen since the vast majority of iron-reducing microorganisms can use one or the other in the reduction of ferric iron and indeed most can draw upon a much wider array of organic compounds (Lloyd, 2003). Iron oxide was synthesized as previously described (Lovley and Phillips, 1986b). $\mathrm{FeCl}_{2}$ (1.3 mM) was added to the medium as a mild reducing agent. Enrichments were set up in triplicate and incubated at 4,15 and $30^{\circ} \mathrm{C}$. Microbial iron reduction was determined by measuring the concentration of $\mathrm{HCl}$-extractable ferrous iron with time, as previously described (Lovley and Phillips, 1986a, b). Secondgeneration 4 and $15^{\circ} \mathrm{C}$ enrichments were initiated in duplicate using a $10 \% v / v$ inoculum from initial enrichments. No $30{ }^{\circ} \mathrm{C}$ initial enrichments were carried over to a secondgeneration since the focus of the study was on the presence of cold-adapted iron-reducing microorganisms. Therefore data presented here are from second-generation 4 and $15^{\circ} \mathrm{C}$ enrichments and first-generation $30^{\circ} \mathrm{C}$ enrichments. A production of $\geq 5 \mathrm{mM} \mathrm{Fe}$ (II) over a period of 50 days was considered positive for microbial iron reduction. This concentration was chosen as a nominal figure that greatly exceeded the typical error of the ferrozine assay, as measured in calibration procedures where triplicate ferrozine measurements are conducted on calibration standards ranging in concentration from 1 to $50 \mathrm{mM}$. Blanks were not initiated in parallel to these enrichments. However, in other experiments using the same medium and electron donor-acceptor couple, no abiotic production of $\mathrm{Fe}$ (II) was observed over a longer period of time (see Fig. S1 in the Supplement).

\subsection{Bacterial community analysis}

DNA was extracted from $5.0 \mathrm{~mL}$ of one replicate of each second-generation $4{ }^{\circ} \mathrm{C}$ enrichment culture using the FastDNA(R) SPIN kit for Soil (MP Biomedicals, Illkirch, France). Each $5 \mathrm{~mL}$ subsample was concentrated by centrifugation at $4570 \times g$ for 15 min (Heraeus Multifuge $3 \mathrm{SR}+$ with swung-out rotor, Thermo Scientific, UK) and resuspended in $500 \mu \mathrm{L}$ sterile basal medium. DNA extraction was carried out according to manufacturer's protocol. Early attempts to extract DNA from $4{ }^{\circ} \mathrm{C}$ LW and F enrichments failed. Subsequent attempts were successful after incorporating the protocol of Direito et al. (2012) to counteract any adsorption of DNA onto clay mineral matrices. Specifically, the FastDNA SPIN kit phosphate buffer was substituted for an equal volume of $1 \mathrm{M}$ sodium phosphate buffer in $15 \%$ moleculargrade ethanol, $\mathrm{pH}$ 8.0. Samples were incubated in a heating block at $80^{\circ} \mathrm{C}$ for $40 \mathrm{~min}$ following the lysis step in the FastDNA SPIN kit protocol. All subsequent processing was as instructed in the manufacturer's protocol.

Extracted DNA from E, L, FL and R enrichments was amplified for the V3 hypervariable region of the $16 \mathrm{~S}$ rRNA gene using primers $27 \mathrm{~F}$ ( $5^{\prime}$-AGA GTT TGA TCC TGG CTC AG-3') and UN1492R (5'-TAC GGT TAC CTT GTT ACG ACT T-3') (Lane, 1991). Each $50 \mu \mathrm{L}$ PCR mixture contained $1 \mu \mathrm{L}$ DNA template, primers $(0.4 \mu \mathrm{M}$ each $)$, deoxynucleoside triphosphates (dNTPs; $200 \mu \mathrm{M}$ ), $1.5 \mathrm{mM} \mathrm{MgCl} 2,5 \mu \mathrm{L} 10 \mathrm{X}$ PCR buffer, $5 \mu \mathrm{L}$ bovine serum albumin (BSA), and $0.5 \mu \mathrm{L}$ Taq polymerase. Template DNA was initially denatured at $94{ }^{\circ} \mathrm{C}$ for $4 \mathrm{~min}$, followed by 30 cycles of denaturing $(30 \mathrm{~s}$ at $\left.94{ }^{\circ} \mathrm{C}\right)$, annealing $\left(30 \mathrm{~s}\right.$ at $\left.55^{\circ} \mathrm{C}\right)$, and extension $(60 \mathrm{~s}$ at $72^{\circ} \mathrm{C}$ ), and a final extension at $72^{\circ} \mathrm{C}$ for $5 \mathrm{~min}$.

DNA extracted from $\mathrm{F}$ and $\mathrm{LW}$ was amplified for the V3 hypervariable region of the $16 \mathrm{~S}$ rRNA gene using primers 357F (5'-CCT ACG GGG AGG CAG CAG-3') and 518R (5'-ATT ACC GCG GCT GCT GG-3') (Muyzer et al., 1993). The PCR mix was kept as described above. For this primer set, template DNA was initially denatured at $94^{\circ} \mathrm{C}$ for $4 \mathrm{~min}$, followed by 35 cycles of denaturing $\left(30 \mathrm{~s}\right.$ at $\left.94^{\circ} \mathrm{C}\right)$, annealing $\left(30 \mathrm{~s}\right.$ at $\left.54^{\circ} \mathrm{C}\right)$ and extension $\left(30 \mathrm{~s}\right.$ at $\left.72^{\circ} \mathrm{C}\right)$, and a final extension at $72^{\circ} \mathrm{C}$ for $5 \mathrm{~min}$.

Amplified DNA was sequenced for bacterial 16S ribosomal RNA using the Roche 454 Pyrosequencing platform (Research and Testing Laboratories, Austin, TX, USA). Resulting sequence reads were quality checked and analysed via the Research and Testing Laboratories pipeline. This analysis is split into two stages. Firstly, sequences were quality trimmed, denoised, and checked for chimeras (Edgar, 2010, 2011; Edgar et al., 2011). Secondly, phylogenetic analysis was carried out, involving clustering sequences into oper- 
ational taxonomic units and using the distributed .NET algorithm BLASTN+ (KrakenBLAST) to query the seed sequence of each cluster against a database of high-quality sequences compiled from the National Center for Biotechnology Information (NCBI). Sequences were resolved to taxonomic levels based on the BLASTN+ derived sequence identity percentage. Species-level identification was assigned to sequences with greater than $97 \%$ identity, genus level is assigned to $95-97 \%$ identity, family level to $90-95 \%$ identity, order level to $85-90 \%$ identity, class level to $80-85 \%$ identity, and phylum level to $77-80 \%$ identity. All sequences characterized by a match of less than $77 \%$ were discarded. Data reported in this study were taken from the counts file of genus-level identification. The Shannon's index of diversity $(H)$ was calculated for genus-assigned sequence datasets for each enrichment.

\section{Results}

\subsection{Occurrence of microbial iron reduction}

Results for positive or negative detection of microbial iron reduction in 4,15 and $30^{\circ} \mathrm{C}$ enrichment cultures after 50 days are summarized in Table 1 . All $4{ }^{\circ} \mathrm{C}$ enrichments tested positive for microbial iron reduction. In contrast, half of enrichments incubated at $15^{\circ} \mathrm{C}$ and only one of six incubated at $30^{\circ} \mathrm{C}$ were positive for microbial $\mathrm{Fe}(\mathrm{III})$ reduction. Particularly high $\mathrm{Fe}(\mathrm{II})$ concentrations were detected in $15^{\circ} \mathrm{C}$ Leverett (L), in which $37.75 \pm 0.002 \mathrm{mM}$ was measured after 58 days.

The relative rates of microbial iron reduction in $4{ }^{\circ} \mathrm{C}$ compared with $15{ }^{\circ} \mathrm{C}$ duplicated enrichments are shown in Fig. 1 and given in Table 2. With the exception of $\mathrm{L}$, significantly greater microbial iron reduction is evident at $T=58$ in $4{ }^{\circ} \mathrm{C}$ compared to $15^{\circ} \mathrm{C}$ enrichments (Student's $t$ test, two-tailed, type 2: $p$ values $<0.005$ ), indicative of cold-tolerant ironreducing microorganisms. In the case of Leverett, iron reduction in the $15^{\circ} \mathrm{C}$ enrichment was significantly higher ( $p$ value $<0.05$ ).

\subsection{Phylogenetic diversity of cold-tolerant enrichment cultures}

Genus-level taxonomic affiliations of 16S rRNA genes amplified from DNA extracted from second-generation $4{ }^{\circ} \mathrm{C}$ enrichments are shown in Fig. 2, along with corresponding Shannon's diversity indices $(H)$. Overall genus-assigned diversity is highest in the second-generation enrichment initiated with L (Shannon's $H$ of 1.92), followed by LW ( $H$ of 1.39), whilst the enrichment initiated from $F$ is characterized by the lowest diversity (Shannon's $H$ of 0.26 ), followed by $\mathrm{E}$ ( $H$ of 0.74$)$. Enrichments from FL and R exhibit similar overall diversity ( $H$ indices of 1.00 and 0.97 , respectively). Sequences affiliated with Desulfosporosinus (95\% sequence match) dominate the second-generation enrichment cultures
Table 1. Occurrence of microbial iron reduction in enrichment cultures. Positive $(+)$ and negative $(-)$ indications refer to secondgeneration duplicated (from single initial) 4 and $15^{\circ} \mathrm{C}$, and initial $30^{\circ} \mathrm{C}$ enrichment cultures. Initial enrichments were inoculated with thawed subglacial sediment in anoxic bicarbonate-buffered medium amended with $\sim 100 \mathrm{mM}$ poorly crystalline ferric iron oxide and $10 \mathrm{mM}$ each of lactate and acetate. Second-generation enrichments were established using a $10 \% v / v$ inoculum from initial enrichments. Microbial iron reduction was monitored by measuring the production of $\mathrm{HCl}$-extractable $\mathrm{Fe}(\mathrm{II})$ over time using the ferrozine assay (Stookey, 1970). Enrichments were considered positive where an increase in $\mathrm{Fe}^{2+}$ concentration $\geq 5 \mathrm{mM}$ (compared with blanks) was measured within 50 days of initiating the enrichment. This concentration was chosen as a nominal figure that significantly exceeded the typical error of the ferrozine assay, as measured in calibration procedures where triplicate ferrozine measurements are conducted on each of five calibration standards ranging from 1 to $50 \mathrm{mM}$.

\begin{tabular}{lccc}
\hline Sample & $4{ }^{\circ} \mathrm{C}$ & $15^{\circ} \mathrm{C}$ & $30^{\circ} \mathrm{C}$ \\
\hline Engabreen (E) & + & - & - \\
Russell (R) & + & - & - \\
Leverett (L) & + & + & + \\
Fresh Leverett (FL) & + & + & - \\
Finsterwalderbreen (F) & + & - & - \\
Lower Wright (LW) & + & + & - \\
\hline
\end{tabular}

Table 2. Rates of microbial iron reduction in second-generation enrichment cultures. Data are expressed as average \pm standard deviation $\mathrm{Fe}^{2+}$ production $(\mu \mathrm{M})$ per $\mathrm{mL}$ of duplicated enrichment per hour.

\begin{tabular}{lcc}
\hline & $\begin{array}{c}\text { Average Fe(II) } \\
\text { production }\end{array}$ & $\left(\mu \mathrm{M} \mathrm{mL}^{-1} \mathrm{~h}^{-1}\right)$ \\
\cline { 2 - 3 } & $4{ }^{\circ} \mathrm{C}$ & $15^{\circ} \mathrm{C}$ \\
\hline Engabreen (E) & $0.8 \pm 0.0$ & $0.1 \pm 0.0$ \\
Finsterwalderbreen (F) & $0.6 \pm 0.0$ & $0.0 \pm 0.0$ \\
Leverett (L) & $1.0 \pm 0.2$ & $1.9 \pm 0.0$ \\
Fresh Leverett (FL) & $2.2 \pm 0.0$ & $0.6 \pm 0.0$ \\
Russell (R) & $1.1 \pm 0.1$ & $0.0 \pm 0.1$ \\
Lower Wright (LW) & $1.6 \pm 0.0$ & $0.8 \pm 0.0$ \\
\hline
\end{tabular}

originating from samples E $(60.3 \%), \mathrm{F}(94.3 \%)$ and LW $(54.6 \%)$ and are present but not dominant in R $(23.0 \%)$ and FL $(3.4 \%)$. In contrast, sequences affiliated with Geobacter (95\% sequence match) dominate enrichments from FL $(78.2 \%)$ and R $(66.0 \%)$. Sequences affiliated with Geobacter are also present in $\mathrm{L}(14.0 \%)$ but are absent in $\mathrm{E}, \mathrm{F}$ and LW. Other identified genera of relevance to microbial iron reduction are Desulfitobacterium (23.5\% of sequence reads from LW) and Rhodoferax ( $18.30 \%$ of sequence reads from L).

A number of the 16S rRNA gene sequences from each enrichment could be resolved to species-level taxonomic 

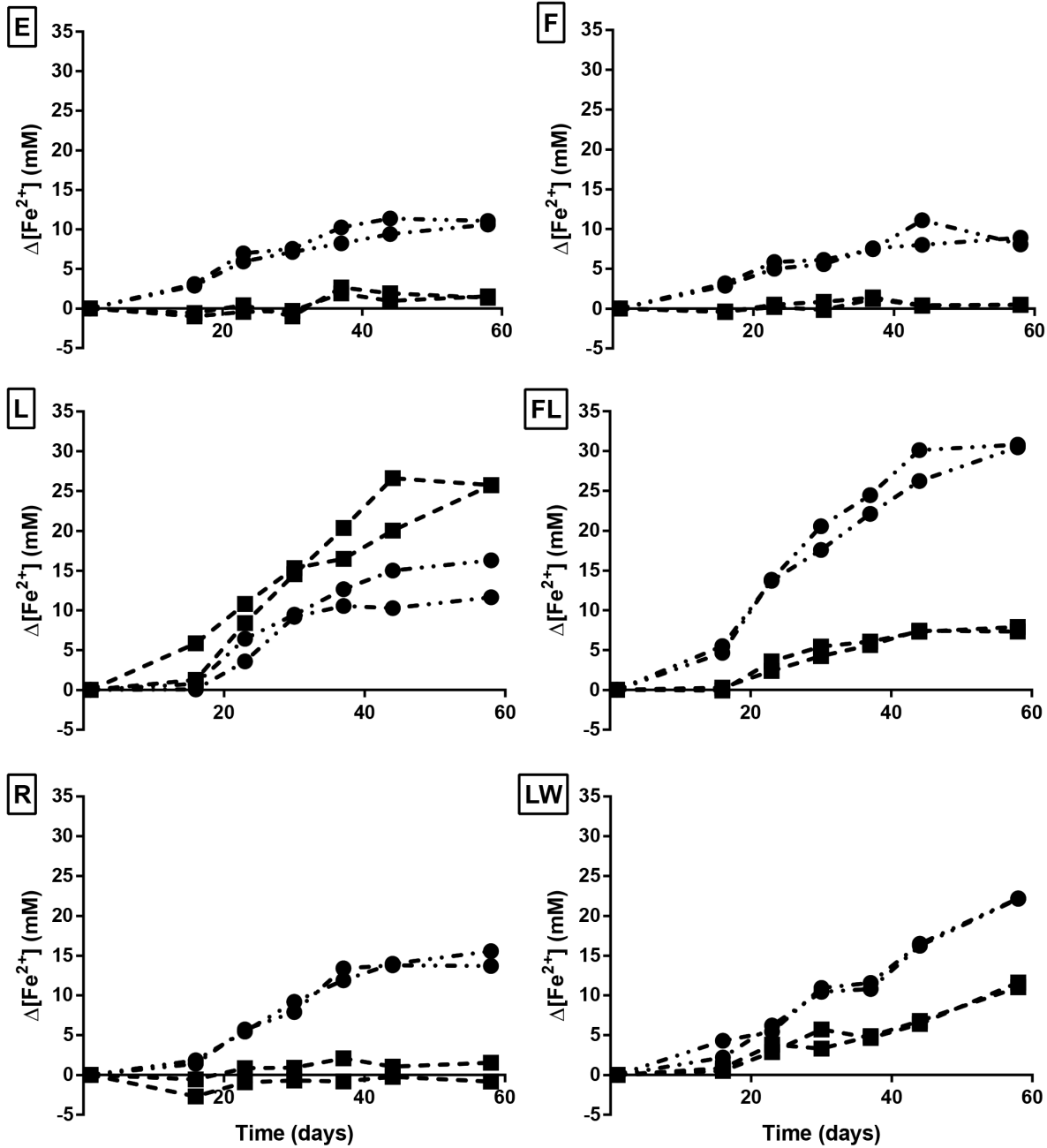

Figure 1. Microbial iron reduction in subglacial enrichments over time. Data, expressed as change in Fe $\mathrm{Fe}^{2+}$ concentration (mM) over time, correspond with second-generation $4{ }^{\circ} \mathrm{C}$ (circles, dot-dashed line) and $15^{\circ} \mathrm{C}$ (squares, dashed line) Engabreen (E), Finsterwalderbreen (F), Leverett (L), fresh Leverett (FL), Russell (R) and Lower Wright (LW) enrichments.

identification. Of relevance for microbial iron reduction are Geobacter psychrophilus (>97\% sequence match), which accounted for $46.3 \%$ of the Geobacter reads in FL; Rhodoferax ferrireducens ( $>97 \%$ sequence match) in enrichments L $(16.2 \%)$ and FL (0.08\%); and Desulfosporosinus lacus (>97\% sequence match) in enrichments E $(0.08 \%)$ and $\mathrm{R}(0.01 \%)$.

\section{Discussion}

\subsection{Distribution and characteristics of iron-reducing microorganisms in subglacial sediments}

Very limited information exists on the distribution and activity of microbial iron reduction beneath glaciers and ice sheets, despite the potential for this process to contribute iron to downstream ecosystems through glacial runoff. The iron- reducing enrichment cultures initiated with subglacial sediments in the present study indicate that viable iron-reducing microorganisms are widespread beneath glaciers and, based on activity data, are likely to be cold-adapted. Members of the Geobacter genus dominate two of the cold temperature enrichments (FL and R) while Desulfosporosinus dominates three of the environments (E, F, LW; see Fig. 2). These two genera appear to be responsible for most of the iron reduction observed, though species of Desulfitobacterium and Rhodoferax may also contribute. Further work is warranted to demonstrate that microorganisms present in these sediments that belong to these genera are indeed capable of microbial iron reduction (MIR) and to attempt to quantify their contribution to iron and carbon cycling in situ.

The possibility that iron reduction detected in the enrichments was indirect cannot be ruled out. Given the prevalence of sulfate-reducing genera such as Desulfosporosinus 


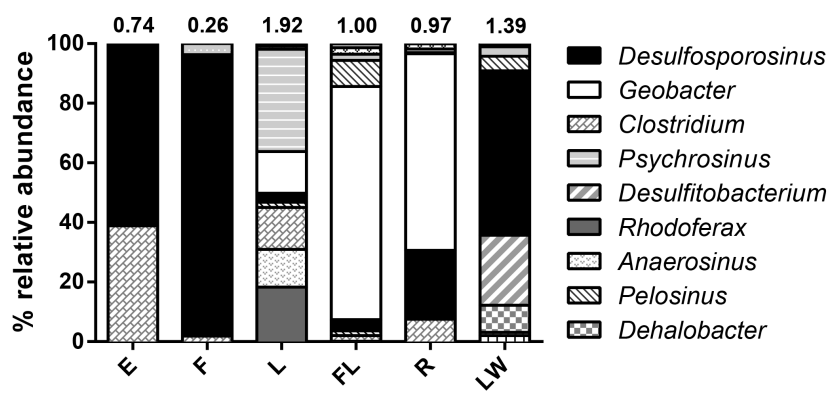

Figure 2. Genus-level taxonomic identification of $16 \mathrm{~S}$ rRNA genes amplified from DNA extracted from second-generation Fe-reducing enrichments incubated at $4{ }^{\circ} \mathrm{C}$ and originated from Engabreen (E), Finsterwalderbreen (F), Leverett (L), "fresh" Leverett (FL), Russell (R) and Lower Wright (LW) glaciers. Data show genera that represent more than $1 \%$ of combined datasets. All genera known to include strains capable of microbial iron reduction, and genera that are assigned to $5 \%$ or more of sequences for each sample, are included in the legend. Shannon's diversity indices calculated using the complete datasets for each sample are given above the corresponding bar in the chart.

in these positive enrichments, the most plausible indirect mechanism of reduction would be via the abiotic reduction of ferric iron by sulfide following microbial sulfate reduction. However no sulfide production (characterized by non-magnetic black precipitate or the recognizable rotten egg smell) was observed in these enrichments. Furthermore, the data presented in Fig. 1 are for second-generation enrichments initiated with a $10 \%(v / v)$ inoculum from initial enrichments. Since no sulfate was added to enrichment medium, and no sulfide was observed in either stage of enrichments, we believe our data provide evidence of direct iron reduction.

Compared to other, less comprehensive studies, our results suggest microbial iron reduction in subglacial environments is characterized by substantial metabolic and genetic diversity. The vast difference in phylogenetic diversity between two low-temperature enrichments initiated with sediments from different locations beneath the Leverett Glacier (Fig. 2) further highlights this diversity. The presence of ironreducing microorganisms in subglacial systems has been identified using culture-independent methods in a number of studies (Skidmore et al., 2005; Mikucki and Priscu, 2007; Lanoil et al., 2009; Yde et al., 2010; Marteinsson et al., 2013; Mitchell et al., 2013), yet only two studies investigated subglacial sediments proximal to those used here. Yde et al. (2010) identified 16S rRNA gene sequences affiliated with the genera Rhodoferax and Geobacter in basal ice from the margin of Russell Glacier. More recently, Cameron et al. (2016) also found evidence for the presence of Rhodoferax, Geobacter and Desulfosporosinus in 16S rRNA gene sequence libraries from subglacial sediments draining Leverett Glacier; of these Rhodoferax was particularly abun- dant, representing more than $20 \%$ of reads in some samples. Similarly, Mitchell et al. (2013) detected 16S rRNA gene sequences affiliated with Rhodoferax in sediments sampled from beneath Robertson Glacier, Alberta, Canada; sequences affiliated with Geobacter were not detected. In this study we detected sequences closely related to Rhodoferax as the dominate sequence type in enrichments from Leverett Glacier (Fig. 2), though sequences affiliated with Geobacter were also detected in the enrichment.

To date, only two studies have enriched for MIR in subglacial sediments. The first, by Foght et al. (2004), enriched for iron-reducing microorganisms in sediments from beneath two temperature glaciers in New Zealand using ferric citrate, yeast extract and tryptone in a semisolid medium. The enrichments were positive for microbial iron reduction, but the study found the microorganisms responsible to be few in number. This is consistent with the expectation that ironreducing microorganisms should not be dominant in subglacial communities, since they depend on a supply of organic carbon from primary producing chemolithoautotrophs (e.g. Boyd et al., 2014). It is possible that organic carbon of pre-glacial origin (legacy organic carbon) could serve as a carbon source, but this has yet to be demonstrated. The second study to enrich for microbial iron reduction was conducted by Mikucki and Priscu (2007), using outflow sediments from Blood Falls in Antarctica as their inoculum and medium containing amorphous iron oxide and yeast extract, with a pressurized $\mathrm{H}_{2}$ headspace. The $16 \mathrm{~S}$ rRNA analysis of the sediment identified sequences closely related to the iron reducer Geopsychrobacter electrodiphilus, although an isolate from a positive microbial iron reduction enrichment was a close relative of Shewanella frigidimarina. In all other studies Rhodoferax has been reported and implicated in subglacial MIR (Skidmore et al., 2005; Lanoil et al., 2009; Mitchell et al., 2013).

Although members of the genera Desulfosporosinus are conventionally thought of as sulfate-reducing bacteria, results from this study serve as compelling evidence that they are capable of low-temperature iron reduction, though visually undetectable levels of sulfate reduction in the enrichment cultures cannot be ruled out. Only one characterized strain belonging to this genus is known to carry out dissimilatory iron reduction: Desulfosporosinus lacus (Ramamoorthy et al., 2006). This species was identified in two of the enrichments in which Desulfosporosinus was abundant, namely Engabreen and Russell. This genus has only been reported in one other study of cold glacial ecosystems (Marteinsson et al., 2013), in which a number of bacterial 16S rRNA gene clones from DNA extracted from subglacial lake sediments from beneath Vatnajökull ice cap in Iceland were closely associated with Desulfosporosinus. The authors hypothesized that Desulfosporosinus is carrying out the reduction of sulfate and other oxidized sulfur species in this environment, whereas Geobacter, also detected in their bacterial clone library, carries out ferric iron reduction. The results from 
our study suggest that Desulfosporosinus may be able to reduce iron in this subglacial lake. Indeed a number of sulfatereducing taxa are capable of conserving energy from iron reduction (e.g. Desulfosporomusa polytropa, Sass et al., 2004; Desulfotalea psychrophilia, Knoblauch et al., 1999), which is consistent with the higher energy yield associated with iron reduction when compared to sulfate reduction (Neal et al., 2003).

Whilst a true determination of psychrophily requires metabolic and growth data, on the basis of activity data alone, the iron-reducing microorganisms enriched in our current study appear to be cold-adapted, and at least cold-tolerant (Fig. 1). While numerous studies have provided evidence for cold-adapted microorganisms (e.g. Thiobacillus sp. RG5; Harrold et al., 2016) and their activities (e.g. nitrification and nitrate reduction (Boyd et al., 2011) and methanogenesis (Telling et al., 2015)), only a handful of iron-reducing microorganisms have been characterized as psychrophilic to date, namely Desulfofrigus oceanense (optimal $T 10^{\circ} \mathrm{C}$, min. $-1.8^{\circ} \mathrm{C}$; Knoblauch et al., 1999), Desulfuromonas svalbardensis and D. ferrireducens (both optimal $14^{\circ} \mathrm{C}$, min. $-2{ }^{\circ} \mathrm{C}$; Vandieken et al., 2006). A larger number of ironreducing microorganisms can tolerate temperatures near or below freezing (e.g. Pelobacter propionicus, Schink, 1984; Lonergan et al., 1996), and the sediment samples used in this study had been frozen to $-20^{\circ} \mathrm{C}$ for months to years prior to use in enrichments. However, the vast majority of characterized iron-reducing strains are psychrotolerant, capable of growth at low temperatures but have much higher optimal growth temperatures, such as strains of Geobacter (Nevin et al., 2005; Sung et al., 2006; Shelobolina et al., 2007, 2008), Desulfuromusa (Liesack and Finster, 1994) and Pelobacter (Schink, 1984). The results from our study suggest that iron-reducing microorganisms in a variety of subglacial ecosystems are adapted to the cold conditions that characterize these environments.

\subsection{Potential controls on activity of iron-reducing microorganisms beneath glaciers}

A key determinant of the in situ activity of iron-reducing microorganisms is the availability of electron donors and ferric iron, as well as the absence of oxidants with higher reduction potentials such as oxygen $\left(\mathrm{O}_{2}\right)$ or manganese oxide $\left(\mathrm{MnO}_{2}\right)$, which should be preferentially utilized for energetic reasons. In anoxic environments depleted in $\mathrm{MnO}_{2}$, understanding the supply of both electron donors and ferric iron is important in constraining the activity of iron-reducing microorganisms in situ. We note that the type and availability of organic matter will vary greatly between subglacial catchments, depending on factors such as hydrological isolation from the surface, timings of advance and retreat over soils and vegetation, and underlying lithology. Although some glaciers have overridden soils, lacustrine or marine deposits rich in organic carbon of different bioavailabilities (e.g. Russell and Leverett glaciers are underlain by palaeosols, Ten Brink and Weidick, 1974; Lower Wright Glacier is underlain by former lacustrine deposits, Wadham et al., 2012), and this legacy organic carbon may represent a source of carbon an electron donors, others are underlain by metamorphic (e.g. Engabreen, Jansson et al., 1996) or carbon-poor igneous bedrock (e.g. Vatnajökull; Marteinsson et al., 2013). In situations where organic carbon is in limited supply, iron-reducing bacteria could augment their supply of reductant using $\mathrm{H}_{2}$ gas, which is supplied to subglacial communities by crushing of the underlying bedrock (Telling et al., 2015), though the concentrations are likely to be low and other microbial metabolisms would compete for it. Although a source of cellular carbon is still required in hydrogen-driven microbial iron reduction, demand for organic compounds would be lower. Therefore the presence of iron-reducing microorganisms in subglacial environments may not be constrained by the amount of bioavailable organic carbon. Future work should incorporate hydrogen utilization tests to demonstrate whether subglacial microbial communities are able to draw upon molecular hydrogen as an electron donor supply.

The supply of ferric iron electron acceptors is also important. Although some iron reducers have been shown to use crystalline iron oxides (e.g. Shewanella oneidensis, Kosta and Nealson, 1995; S. alga, Roden and Zachara, 1996; Geobacter sulfurreducens, Cutting et al., 2009), the vast majority of characterized strains prefer poorly crystalline iron oxides and oxyhydroxides, and it is for this reason that poorly crystalline oxyhydroxide was chosen as the terminal electron acceptor in the enrichments reported on here. Ferrihydrite has been widely reported in glacial sediments and meltwater (Raiswell et al., 2009; Hawkings et al., 2014), and it is generated as a reaction product of pyrite oxidation (Mitchell et al., 2001) or oxidation of other iron-bearing minerals. Interestingly, incubation of the crystalline iron oxides hematite and magnetite in the subglacial meltwater stream at Robertson Glacier resulted in higher biomass loadings than other silicate or carbonate minerals, suggesting that these minerals were being used in energy metabolism (Mitchell et al., 2013). While magnetite has not been detected in sediments from Robertson, hematite has been detected, albeit in low amounts (Skidmore, unpublished data). Thus, the range of electron donors and types of ferric iron electron acceptors available in subglacial environments is therefore likely to be more varied than those used in this study. If so, then the true diversity of iron-reducing microorganisms in the glacial systems studied here is likely to be under-represented.

\subsection{Implications for iron export from glacial systems}

Recent research has shown the flux of bioavailable nanoparticulate iron associated with glacial runoff from ice sheets to be an important source of nutrients to the surrounding oceans (Hawkings et al., 2014). Importantly, these iron oxyhydroxide particles are thought to originate from the oxidation of 
dissolved ferrous iron from anoxic subglacial environments. The source of this Fe(II) remains unknown, though microbial iron reduction is a plausible, albeit undemonstrated, explanation (Hawkings et al., 2014). Results from our study indicate that microbial $\mathrm{Fe}(\mathrm{III})$ reduction is a possible source of the $\mathrm{Fe}$ (II) emanating from glaciers worldwide and may be responsible for a portion of the $\mathrm{Fe}(\mathrm{III})$ flux to marine ecosystems from glacial systems. Since Fe(III) availability often limits the primary production of marine phototrophs, the activity of iron-reducing bacteria in subglacial environments could have an indirect but significant effect on global carbon budgets (Statham et al., 2008; Death et al., 2013). Iron cycling can also have an important impact on the availability of phosphorus to microorganisms, due to the adsorption of phosphorus to solid phase Fe oxyhydroxide particles (Gunnars et al., 2002). Further studies are required to characterize in situ $\mathrm{Fe}(\mathrm{III})$ reducing metabolic activity and to quantify its impact on the export of bioavailable iron to past and present marine ecosystems. Subglacial environments are considered analogous to potential habitats for life on Mars (Skidmore et al., 2000; Christner et al., 2008; Fisher and Schulze-Makuch, 2013), and microbial iron reduction has been identified as a plausible metabolism to fuel microbial life (Nixon et al., 2012). This study lends weight to this hypothesis and suggests similar past or present perennially cold and dark environments are within the bounds of habitability.

\section{Data availability}

The raw sequencing data have been submitted to NCBI Sequence Read Archive (https://www.ncbi.nlm.nih.gov/ bioproject/PRJNA374495, Nixon et al., 2017) with the project accession number of SRP099404 (samples E, L, FL and $R$ are under accession no. SRR5332312 and samples LW and $\mathrm{F}$ under accession no. SRR5332311).

\section{The Supplement related to this article is available online at doi:10.5194/bg-14-1445-2017-supplement.}

Competing interests. The authors declare that they have no conflict of interest.

Acknowledgements. We are grateful to Eric Boyd and Mark Skidmore for their helpful comments on the manuscript. We thank Chris Boothman for his assistance submitting sequencing data to NCBI. Sophie L. Nixon was supported by a PhD studentship from the STFC/UK Space Agency under the Aurora Programme.

Edited by: T. J. Battin

Reviewed by: M. Stibal and B. Lanoil

\section{References}

Bhatia, M., Sharp, M., and Foght, J.: Distinct bacterial communities exist beneath a High Arctic polythermal glacier, Appl. Environ. Microbiol., 72, 5838-5845, 2006.

Bottrell, S. H. and Tranter, M.: Sulphide oxidation under partially anoxic conditions at the bed of the Haut Glacier d'Arolla, Switzerland, Hydrol. Process., 16, 2363-2368, 2002.

Boyd, E. S., Lange, R. K., Mitchell, A. C., Havig, J. R., Hamilton, T. L., Lafrenière, M. J., Shock, E. L., Peters, J. W., and Skidmore, M.: Diversity, abundance, and potential activity of nitrifying and nitrate-reducing microbial assemblages in a subglacial ecosystem, Appl. Environ. Microbiol., 77, 4778-4787, 2011.

Boyd, E. S., Hamilton, T. L., Havig, J. R., Skidmore, M. L., and Shock, E. L.: Chemolithotrophic primary production in a subglacial ecosystem, Appl. Environ. Microbiol., 80, 6146-6153, 2014.

Buzzini, P., Turchetti, B., Diolaiuti, G., D’Agata, C., Martini, A., and Smiraglia, C.: Culturable yeasts in the meltwaters draining from two glaciers in the Italian Alps, Ann. Glaciol., 40, 119-122, 2005.

Cameron, K. A., Stibal, M., Hawkings, J. R., Mikkelsen, A. B., Telling, J., Kohler, T. J., Gözdereliler, E., Zarsky, J. D., Wadham, J. L., and Jacobsen, C. S.: Meltwater export of prokaryotic cells from the Greenand ice sheet, Environ. Microbiol., 19, doi:10.1111/1462-2920, 2016.

Christner, B. C., Skidmore, M. L., Priscu, J. C., Tranter, M., and Foreman, C. M.: Bacteria in subglacial environments, in Psychrophiles: from Biodiversity to Biotechnology, edited by: Margesin, R., Schinner, F., Marx, J.-C., and Gerday, C., SpringerVerlag, Berlin, 51-71, 2008.

Christner, B. C., Priscu, J. C., Achberger, A. M., Barbante, C., Carter, S. P., Christianson, K., Michaud, A. B., Mikucki, J. A., Mitchell, A. C., Skidmore, M. L., and Vick-Majors, T. J.: A microbial ecosystem beneath the West Antarctic ice sheet, Nature, 512, 310-313, 2014.

Cutting, R. S., Coker, V. S., Fellowes, J. W., Lloyd, J. R., and Vaughan, D. J.: Mineralogical and morphological constraints on the reduction of $\mathrm{Fe}$ (III) minerals by Geobacter sulfurreducens, Geochim. Cosmochim. Acta, 73, 4004-4022, 2009.

Dallmann, W. K., Hjelle, A., Ohta, Y., Salvigsen, O., Bjornerud, M. G., Hauser, E. C., Maher, H. D., and Craddock, C.: Geological map of Svalbard 1:100 000: Sheet B11G Van Keulenfjorden, Norsk Polarinstitutt, Oslo, 1990.

Death, R., Wadham, J. L., Monteiro, F., Le Brocq, A. M., Tranter, M., Ridgwell, A., Dutkiewicz, S., and Raiswell, R.: Antarctic ice sheet fertilises the Southern Ocean, Biogeosciences, 11, 26352643, doi:10.5194/bg-11-2635-2014, 2014.

Direito, S. O. L., Marees, A., and Röling, F. M.: Sensitive life detection strategies for low-biomass environments: optimizing extraction of nucleic acids adsorbing to terrestrial and Mars analogue minerals, FEMS Microbial Ecol., 81, 111-123, 2012.

Edgar, R. C.: Search and clustering orders of magnitude faster than BLAST, Bioinformatics, 26, 2460-2461, 2010.

Edgar, R. C.: UPARSE: highly accurate OUT sequences from microbial amplicon reads, Nature Methods, 10, 996-998, 2011.

Edgar, R. C., Haas, B. J., Clemente, J. C., Quince, C., and Knight, R.: UCHIME improves sensitivity and speed of chimera detection, Bioinformatics, 27, 2194-2200, 2011. 
Fisher, T. M. and Schulze-Makuch, D.: Nutrient and population dynamics in a subglacial reservoir: a simulation case study of the Blood Falls ecosystem with implications for astrobiology, Int. J. Astrobiol., 12, 304-311, 2013.

Foght, J., Aislabie, J., Turner, S., Brown, C. E., Ryburn, J., Saul, D. J., and Lawson, W.: Culturable bacteria in subglacial sediments ad ice from two southern hemisphere glaciers, Microbial Ecol., 47, 329-340, 2004.

Gaidos, E., Lanoil, B., Thorsteinsson, T., Graham, A., Skidmore, M., Han, S.-K., Rust, T., and Popp, B.: A viable microbial community in a subglacial volcanic crater lake, Iceland, Astrobiology, 4, 327-344, 2004.

Gunnars, A., Blomqvist, S., Johansson, P., and Andersson, C.: Formation of $\mathrm{Fe}(\mathrm{III})$ oxyhydroxide colloids in freshwater and brackish seawater, with incorporation of phosphate and calcium, Geochim. Cosmochim. Acta, 66, 745-758, 2002.

Hall, B. L. and Denton, G. H.: Holocene history of the Wilson Piedmont Glacier along the southern Scott Coast, Antarctica, The Holocene, 12, 619-627, 2002.

Hamilton, T. L., Peters, J. W., Skidmore, M. L., and Boyd, E. S.: Molecular evidence for an active endogenous microbiome beneath glacial ice, ISME, 7, 1402-1412, 2013.

Harrold, Z. R., Skidmore, M. L., Hamilton, T. L., Desch, L., Amada, K., van Gelder, W., Glover, K., Roden, E. R., and Boyd, E. S.: Aerobic and anaerobic thiosulfate oxidation by a coldadapted, subglacial chemoautotroph, Appl. Environ. Microbiol., 82, 1486-1495, 2016.

Hawkings, J. R., Wadham, J. L., Tranter, M., Raiswell, R., Benning, L. G., Statham, P. J., Tedstone, A., Nienow, P., Lee, K., and Telling, J.: Ice sheets as a significant source of highly reactive nanoparticulate iron to the oceans, Nature Comm., 5, 3929, doi:10.1038/ncomms4929, 2014.

Henrikson, N., Higgins, A. K., Kalsbeek, F., and Pulvertaft, T. C. R.: Greenland from Archaean to Quaternary: descriptive text to the geological map of Greenland, 1:2 500 000, Geology of Greenland Survey Bulletin, 185, 2000.

Hodson, A. J. and Ferguson, R. I.: Fluvial suspended sediment transport from cold and warm-based glaciers in Svalbard, Earth Surf. Process. Landforms, 24, 957-974, 1999.

Hodson, A., Anesio, A. M., Tranter, M., Fountain, A., Osborn, M., Priscu, J., Laybourn-Parru, J., and Sattler, B.: Glacial ecosystems, Ecol. Monogr., 78, 41-67, 2008.

Jansson, P., Kohler, J., and Pohjola, V. A.: Characteristics of basal ice at Engabreen, northern Norway, Ann. Glaciol., 22, 114-120, 1996.

Kaštovská, K., Stibal, M., Šabacká, M., Černá, B., Šantrůčková, H., and Elster, J.: Microbial community structure and ecology of subglacial sediments in two polythermal Svalbard glaciers characterized by epifluorescence microscopy and PLFA, Polar Biol., 30, 277-287, 2007.

Knoblauch, C., Sahm, K., and Jørgensen, B. B.: Psychrophilic sulfate-reducing bacteria isolated from permanently cold Arctic marine sediments: description of Desulfofrigus oceanense gen. nov., sp. nov., Desulfofrigus fragile sp. nov., Desulfofaba gelida gen. nov., sp. nov., Desulfotalea psychrophila gen. nov., sp. nov. and Desulfotalea arctica sp. nov., International Journal of Systematic and Evolutionary Microbiology, 49, 1631-1643, 1999.

Kosta, J. E. and Nealson, K. H.: Dissolution and reduction of magnetite by bacteria, Environ. Sci. Technol., 29, 2535-2540, 1995.
Lane, D. J.: 16S/23S rRNA sequencing, in: Nucleic Acid Techniques in Bacterial Systematics, edited by: Stackenbradt, E. and Goodfellow, M., Wiley, Chichester, 115-175, 1991.

Lanoil, B., Skidmore, M., Priscu, J. C., Han, S., Foo, W., Vogel, S. W., Tulaczyk, S., and Engelhardt, H.: Bacteria beneath the West Antarctic Ice Sheet, Environ. Microbiol., 11, 609-615, 2009.

Liesack, W. and Finster, K.: Phylogenetic analysis of five strains of gram-negative, obligately anaerobic, sulphur-reducing bacteria and description of Desulfuromusa gen. nov., including Desulfuromusa kysingii sp. nov., Desulfuromusa bakii sp. nov., and Desulfuromusa succinoxidans sp. nov., International Journal of Systematic Bacteriology, 44, 753-758, 1994.

Lloyd, J. R.: Microbial reduction of metals and radionuclides, FEMS Microbiol. Rev., 27, 411-425, 2003.

Lonergan, D. J., Jenter, H. J., Coates, J. D., Phillips, E. J. P., Schmidt, T. M., and Lovley, D. R.: Phylogenetic analysis of dissimilatory Fe(III)-reducing bacteria, J. Bacteriol., 178, 24022408, 1996.

Lovley, D. R. and Phillips, E. J. P.: Availability of ferric iron for microbial reduction in bottom sediments of the freshwater tidal Potomac River, Appl. Environ. Microbiol., 52, 751-757, 1986a.

Lovley, D. R. and Phillips, E. J. P.: Organic-matter mineralization with reduction of ferric iron in anaerobic sediments, Appl. Environ. Microbiol., 51, 683-689, 1986 b.

Marteinsson, V. T., Rúnarsson, Á., Stefánsson, A., Thorsteinsson, T., Jóhannesson, T., Magnússon, S. H., Reynisson, E., Einarsson, B., Wade, N., Morrison, H. G., and Gaidos, E.: Microbial communities in the subglacial waters of the Vatnajökull ice cap, Iceland, The International Society for Microbial Ecology Journal, 7, 427-437, 2013.

Mikucki, J. A. and Priscu, J. C.: Bacterial diversity associated with Blood Falls, a subglacial outflow from the Taylor Glacier, Antarctica, Appl. Environ. Microbiol., 73, 4029-4039, 2007.

Miller, T. L. and Wolin, M. J.: A serum bottle modification of the Hungate technique for cultivating obligate anaerobes, Appl. Microbiol., 27, 985-987, 1974.

Mitchell, A., Brown, G. H., and Fuge, R.: Minor and trace element export from glacierized Alpine headwater catchment (Haut Glacier d'Arolla, Switzerland), Hydrol. Process., 15, 3499-3524, 2001.

Mitchell, A. C., Lafrenière, M. J., Skidmore, M. L., and Boyd, E. S.: Influence of bedrock mineral composition on microbial diversity in a subglacial environment, Geology, 41, 855-858, 2013.

Montross, S. N., Skidmore, M., Tranter, M., Kivimäki, A.-L., and Parkes, R. J.: A microbial driver of chemical weathering in glaciated systems, Geology, 41, 215-218, 2012.

Muyzer, G., de Waal, E. C., and Uitterlinder, A. G.: Profiling of complex microbial populations by denaturing gradient gel electrophoresis analysis of polymerase chain reaction-amplified genes coding for 16S rRNA, Appl. Environ. Microbiol., 59, 695700, 1993.

Neal, A. L., Rosso, K. M., Geesey, G. G., Gorby, Y. A., and Little, B. J.: Surface structure effects on direct reduction of iron oxides by Shewanella oneidensis, Geochim. Cosmochim. Acta, 67, 44894503, 2003.

Nevin, K. P., Holmes, D. E., Woodard, T. L., Hinlein, E. S., Ostendorf, D. W., and Lovley, D. R.: Geobacter bemidjiensis sp. nov. and Geobacter psychrophilus sp. nov., two novel Fe(III)- 
reducing subsurface isolates, International Journal of Systematic and Evolutionary Microbiology, 55, 1667-1674, 2005.

Nixon, S. L., Cockell, C. S., and Tranter, M.: Limitations to a microbial iron cycle on Mars, Planet. Space Sci., 72, 116-128, 2012.

Nixon, S. L., Telling, J. P., Wadham, J. L., and Cockell, C. S.: Uncultured Environmental Isolate, available at: https://www.ncbi. nlm.nih.gov/bioproject/PRJNA374495, 2017.

O’Donnell, E. C., Wadham, J. L., Lis, G. P., Tranter, M., Pickard, A. E., Stibal, M., Dewsbury, P., and Fitzsimons, S.: Identification and analysis of low-molecular-weight dissolved organic carbon in subglacial basal ice ecosystems by ion chromatography, Biogeosciences, 13, 3833-3846, doi:10.5194/bg-13-3833-2016, 2016.

Priscu, J. C., Adams, E. E., Lyons, W. B., Voytek, M. A., Mogk, D. W., Brown, R. L., McKay, C. P., Takacs, C. D., Welch, K. A., Wolf, C. F., Kirshtein, J. D., and Avci, R.: Geomicrobiology of subglacial ice above Lake Vostok, Antarctica, Science, 286, 2141-2144, 1999.

Raiswell, R., Benning, L. G., Davidson, L., Tranter, M., and Tulaczyk, S.: Schwertmannite in wet, acid, and oxic microenvironments beneath polar and polythermal glaciers, Geology, 37, 431434, 2009.

Ramamoorthy, S., Sass, H., Langner, H., Schumann, P., Kroppenstedt, R. M., Spring, S., Overmann, J., and Rosenzweig, R. F.: Desulfosporosinus lacus sp. nov., a sulfate-reducing bacterium isolated from pristine freshwater lake sediments, International Journal of Systematic and Evolutionary Microbiology, 56, 27292736, 2006.

Roden, E. E. and Zachara, J. M.: Microbial reduction of crystalline iron(III) oxides: Influence of oxide surface area and potential for cell growth, Environ. Sci. Technol., 30, 1618-1628, 1996.

Sass, H., Overmann, J., Rütters, H., Babenzien, H.-D., and Cypionka, H.: Desulfosporomusa polytropa gen. nov., sp. nov., a novel sulfate-reducing bacterium from sediments of an oligotrophic lake, Arch. Microbiol., 182, 204-211, 2004.

Schink, B.: Fermentation of 2,3-butanediol by Pelobacter carbinolicus sp. nov. and Pelobacter propionicus sp. nov., and evidence for propionate formation from $\mathrm{C}_{2}$ compounds, Arch. Microbiol., 137, 33-41, 1984.

Sharp, M., Parkes, J., Cragg, B., Fairchild, I. J., Lamb, H., and Tranter, M.: Widespread bacterial populations at glacier beds and their relationship to rock weathering and carbon cycling, Geology, 27, 107-110, 1999.

Shelobolina, E. S., Nevin, K. P., Blakeney-Hayward, J. D., Johnsen, C. V., Plaia, T. W., Krader, P., Woodard, T., Holmes, D. E., Gaw Van Praagh, C. V., and Lovley, D. R.: Geobacter pickeringii sp. nov., Geobacter argillaceus sp. nov. and Pelosinus fermentans gen. nov., sp. nov., isolated from subsurface kaolin lenses, International Journal of Systematic and Evolutionary Microbiology, 57, 126-135, 2007.

Shelobolina, E. S., Vrionis, H. A., Findlay, R. H., and Lovley, D. R.: Geobacter uraniireducens sp. nov., isolated from subsurface sediment undergoing uranium bioremediation, International Journal of Systematic and Evolutionary Microbiology, 58, 1075-1078, 2008.

Sheridan, P. P., Miteva, V. I., and Brenchley, J. E.: Phylogenetic analysis of anaerobic psychrophilic enrichment cultures obtained from a Greenland glacier ice core, Appl. Environ. Microbiol., 69, 2153-2160, 2003.
Skidmore, M. L., Foght, J. M., and Sharp, M. J.: Microbial life beneath a high Arctic glacier, Appl. Environ. Microbiol., 66, 3214 3220, 2000.

Skidmore, M., Anderson, S. P., Sharp, M., Foght, J., and Lanoil, B. D.: Comparison of microbial community compositions of two subglacial environments reveals a possible role for microbes in chemical weathering processes, Appl. Environ. Microbiol., 71, 6986-6997, 2005.

Statham, P. J., Skidmore, M., and Tranter, M.: Inputs of glacially derived dissolved and colloidal iron to the coastal ocean and implications for primary productivity, Global Biogeochem. Cy., 22 , GB3032, doi:10.1029/2007GB003106, 2008.

Stibal, M., Wdham, J. L., Lis, G. P., Telling, J. P., Pancost, R. D., Dubnick, A., Sharp, M. J., Lawson, E. C., Butler, C. E., Hasan, F., Tranter, M., and Anesio, A. M. B.: Methanogenic potential of Arctic and Antarctic subglacial environments with contrasting organic carbon sources, Glob. Change Biol., 18, 3332-3345, doi:10.1111/j.1365-2486.2012.02763.x, 2012.

Stibal, M., Wadham, J. L., Lis, G. P., Telling, J., Pancost, R. D., Dubnick, A., Sharp, M. J., Lawson, E. C., Butler, C. E. H., Hasan, F., Tranter, M., and Anesio, A. M.: Methanogenic potential of Arctic and Antarctic subglacial environments with contrasting organic carbon sources, Glob. Change Biol., 18, 3332 3345, 2016.

Stookey, L. L.: Ferrozine - a new spectrophotometric reagent for iron, Anal. Chem., 42, 779-781, 1970.

Sundal, A. V., Shepherd, A., Nienow, P., Hanna, E., Palmer, S., and Huybrechts, P.: Melt-induced speed-up of Greenland ice sheet offset by efficient subglacial drainage, Nature, 469, 521-524, 2011.

Sung, Y., Fletcher, K. E., Ritalahti, K. M., Apkarian, R. P., Ramos-

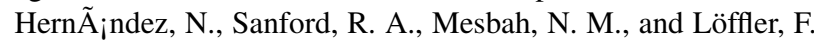
E.: Geobacter lovleyi sp. nov. Strain SZ, a novel metal-reducing and tetrachloroethene-dechlorinating bacterium, Appl. Environ. Microbiol., 72, 2775-2782, 2006.

Telling, J., Boyd, E. S., Bone, N., Jones, E. L., Tranter, M., MacFarlane, J. W., Martin, P. G., Wadham, J. L., Lamarche-Gagnon, G., Skidmore, M. L., Hamilton, T. L., Hill, E., Jackson, M., and Hodgson, D. A.: Rock communition as a source of hydrogen for subglacial ecosystems, Nature Geosci., 8, 851-855, 2015.

Ten Brink, N. W. and Weidick, A.: Greenland ice sheet history since the last glaciation, Quaternary Res., 4, 429-440, 1974.

Tranter, M., Skidmore, M., and Wadham, J.: Hydrological controls on microbial communities in subglacial environments, Hydrol. Process., 19, 995-998, 2005.

Vandieken, V., Mußmann, M., Niemann, H., and Jørgensen, B. B.: Desulfuromonas svalbardensis sp. nov. and Desulfuromusa ferrireducens sp. nov., psychrophilic, $\mathrm{Fe}(\mathrm{III})$-reducing bacteria isolated from Arctic sediments, Svalbard, International Journal of Systematic and Evolutionary Microbiology, 56, 1133-1139, 2006.

Wadham, J. L. and Nuttall, A.-M.: Multiphase formation of superimposed ice during a mass-balance year at a maritime highArctic glacier, J. Glaciol., 48, 545-555, 2002.

Wadham, J. L., Arndt, S., Tulaczyk, S., Stibal, M., Tranter, M., Telling, J., Lis, G. P., Lawson, E., Ridgwell, A., Dubnick, A., Sharp, M. J., Anesio, A. M., and Butler, C. E. H.: Potential methane reservoirs beneath Antarctica, Nature, 488, 633-637, 2012. 
Wynn, P. M., Hodson, A., and Heaton, T.: Chemical and isotopic switching within the subglacial environment of a High Arctic glacier, Biogeochemistry, 78, 173-193, 2006.
Yde, J. C., Finster, K. W., Raiswell, R., Steffensen, J. P., Heinemeier, J. Olsen, J., Gunnlaugsson, H. P., and Nielson, O. B.: Basal ice microbiology at the margin of the Greenland ice sheet, Ann. Glaciol., 51, 71-79, 2010 